\title{
An Alternative Activated Carbon from Agricultural Waste on Chromium Removal
}

\author{
Mohammad Mahmudi 1,3, Sulastri Arsad ${ }^{1,3,4}$, Mega Charisma Amelia ${ }^{2}$, \\ Hajar Alviyyah Rohmaningsih ${ }^{2}$, Fiddy Semba Prasetiya ${ }^{5}$
}

1 Department of Aquatic Resources Management, Faculty of Fisheries and Marine Science, Universitas Brawijaya, Jl. Veteran Malang 65145, Indonesia

2 Undergraduate Students at Faculty of Fisheries and Marine Science, Universitas Brawijaya, Jl. Veteran Malang 65145, Indonesia

3 AquaRES Research Group, Faculty of Fisheries and Marine Science, Universitas Brawijaya. Jl. Veteran Malang 65145, Indonesia

4 MicroBase Research Group, Postgraduate Department, Universitas Brawijaya, Jl. Veteran Malang 65145, Indonesia

5 Department of Marine Science, Faculty of Fisheries and Marine Science, Universitas Padjadjaran, JI Raya Jatinangor KM 21 Sumedang 45363, West Java, Indonesia

* Corresponding author's e-mail: mudi@ub.ac.id

\begin{abstract}
Corn cobs and bagasse are materials used for making activated carbon that are easy to find. Additionally, they are agricultural waste that cannot be consumed. This study aims to analyze the potential of activated carbon from agricultural waste, namely corn cobs and bagasse, in reducing the levels of chromium heavy metal, and to analyze the dose of activated carbon from agricultural waste which is effective in reducing the chromium levels in the batik waste. The method used was experimental with a completely randomized factorial design. The doses of activated carbon used were $0.5,1.5$, and $2.5 \mathrm{~g}$. Meanwhile, the contact times used were 30,60, 90, 120, and 150 minutes. The results showed that the initial chromium content was $0.144 \mathrm{mg} \cdot \mathrm{L}^{-1}$, and after given treatment it decreased to below $0.024 \mathrm{mg} \cdot \mathrm{L}^{-1}$. The activated carbon from corn cobs and bagasse was able to reduce the chromium levels with the most effective dose of $2.5 \mathrm{~g} \cdot \mathrm{L}^{-1}$ and a contact time of 120 minutes. Meanwhile, the water quality parameters showed temperature stability $\left(23-25^{\circ} \mathrm{C}\right)$ during the experimental period, while the $\mathrm{pH}$ increased to 9-11.
\end{abstract}

Keywords: heavy metals, activated carbon, corn cobs, bagasse.

\section{INTRODUCTION}

Batik is a typical Indonesian clothing (Iskandar \& Kustiyah, 2017; Steelyana, 2012). The batik industry has great potential for development. Batik is produced commercially both on a large scale by factories and on a small scale by home industries. However, in the process of making batik, from the initial process to the refinement process the chemicals containing heavy metal elements are used so that the waste materials still contain these elements (Setiono \& Gustaman, 2017; Puspita et al., 2011). The batik waste in the form of liquid material contains heavy metals as a result of the dyeing and washing processes (Wirosoedarmo et al, 2020; Kurniawan et al., 2014).

In general, industrial waste passes through a treatment process before being discharged into the environment, but for some home industries, the resulting waste is directly discharged into the environment without any prior treatment. High metal concentrations in waste, when polluting the water, can cause adverse effects on the environment and human life (Puspita et al., 2011). The heavy metals dissolved in water bodies at certain concentrations will turn into a source of poison 
for aquatic life (Puspasari, 2006). Although the toxicity caused by one heavy metal to all aquatic biota is not the same, the loss of a certain group of organisms can lead to a break in an ecosystem chain. At an advanced level, this situation can of course destroy one aquatic ecosystem order (Apriadi, 2005; Sasongko, 2010). One of the harmful batik waste products is the chromium heavy metal $(\mathrm{Cr})$.

The high level of contamination in the waters will affect the physiological condition of fish, accompanied by anatomical damage (Kusumadewi et al., 2015). The impact of chromium on aquatic organisms is the disruption of the body metabolism due to the obstruction of the work of enzymes in the physiological processes in which chromium can accumulate in the body and is also chronic, which ultimately results in the death of the organisms (Mason, 2002). The accumulation of chromium can cause damage to the respiratory organs and can also cause cancer in humans (Kristianto et al., 2017). The chromium in the body is usually in the $\mathrm{Cr}^{3+}$ ion state. Chromium can cause lung cancer, and liver and kidney damage. The physical contact between chromium and skin can cause irritation and, if ingested, may cause stomachache and vomiting. The allowable concentration of the $\mathrm{Cr}$ metal in the water is $0.05 \mathrm{mg} \cdot \mathrm{L}^{-1}$ (Effendi, 2003). Therefore, the heavy metal content, especially $\mathrm{Cr}$, in the industrial waste that exceeds the permissible limit must be minimized before being discharged into the environment (Diantariani et al., 2010).

One alternative effort to reduce the heavy metal content in the batik waste can be through adsorption using activated carbon. Activated carbon is a porous solid containing $85-95 \%$ carbon (Siregar et al., 2015). The materials that contain the carbon element can produce activated carbon by heating them at high temperatures (Chand et al., 2015). These pores can be used as an adsorbent agent. Activated carbon with a large surface area can be used in the water purification process both in the drinking water production process and in the waste handling (Idrus et al., 2013). The characteristics of activated carbon basically include the adsorption properties and physical properties including total surface area, particle density, and effective size. Meanwhile, the chemical properties of the surface greatly determine the occurrence of the adsorption process in which it is easier to bind the particles that have similar properties (Udyani, 2013).
Corn cobs and bagasse are materials used for making activated carbon that are easy to find. Additionally, they are agricultural waste that cannot be consumed. After the corns and sugarcane are consumed, the cobs and bagasse are just thrown away because they are no longer useful. The use of corn cobs and bagasse as activated carbon for waste adsorption and water purification is still not widely known by the public.

In fact, the use of alternative sources of activated carbon is one of the cheap and effective methods to reduce the heavy metal levels compared to other methods such as adding chemicals to reduce the concentration of pollutants, using microorganisms and disinfection, or killing germs. Several studies on activated carbon have also been conducted (Amin et al., 2016; Alverina et al., 2014; Alfiany et al, 2013).

This study aims to analyze the potential of activated carbon from agricultural waste, namely corn cobs and bagasse, in reducing the levels of chromium heavy metal, and to analyze the dose of activated carbon from agricultural waste which is effective in reducing the chromium levels in the batik waste.

\section{MATERIALS AND METHODS}

\section{The making of activated carbon from agricultural waste}

The materials in this study included the making of activated carbon made from corn cobs (Zea mays $L$ ) in several stages, namely dehydration, carbonization and chemical activation, and the contact between the batik waste with activated carbon of corn cobs (Shofa, 2012). The raw materials for making activated carbon in this study were obtained from corn farmers in Sumberpucung District, Malang Regency. The process of making activated carbon on corn cobs began with washing the corns using running water to remove the dirt that stuck to the corn cobs until they were clean. Afterwards, the dehydration process was conducted by drying the corn cobs under the sun until they were completely dry for \pm 2 days. The next step was the carbonization by burning the corn cobs for 2 hours until charcoals were formed. After charcoals or carbon was formed, the next step was to grind them and sieve into fine particles using a sieve with a mesh size of $500 \mu \mathrm{m}$ (Alfiany et al., 2013). After the sieving process, 
the corn cobs with an initial weight of approximately $3 \mathrm{~kg}$ would produce as much as $138 \mathrm{~g}$ of charcoal powder (Figure 1). Then, the activation process was carried out. The resulting carbon was in the form of powder, which was then physically activated in an oven for $200{ }^{\circ} \mathrm{C}$ for 2 hours (Marsh and Francisco, 2006).

The making of activated carbon from bagasse was based on the modification of Asbahani's research (2013), starting with washing the bagasse to remove soil and other impurities, if any. The bagasse was then cut $\pm 0.5 \mathrm{~cm}$ and was dried under the sun for one day. After drying, the bagasse was burned until it became charcoal (black). After cooling down, it was ground and sieved into fine particles $\pm 0.5 \mathrm{~mm}$. Then, the charcoal particles were placed in an oven at a temperature of $100{ }^{\circ} \mathrm{C}$ for 2 hours (Figure 2). The bagasse used in this study was obtained from the sugar factory area in Kediri, East Java.

\section{Characteristics of the batik waste}

The batik waste used in this study was obtained from the batik home industries located in the Malang City. The batik waste used was the result of the batik dyeing and washing processes. The characteristics of the batik waste before having a contact with activated carbon on corn cobs were at its temperature of $25^{\circ} \mathrm{C}, \mathrm{pH}$ of 8.4 and the $\mathrm{Cr}$ content of $0.144 \mathrm{mg} \cdot \mathrm{L}^{-1}$. This result was still above the quality standard for the $\mathrm{Cr}$ content allowed in the waters, which is $0.05 \mathrm{mg} \cdot \mathrm{L}^{-1}$ (Effendi, 2003). Therefore, this batik waste was still dangerous if it was directly discharged into the water without any treatment. In terms of the physical characteristics of the batik waste before the application activated carbon, it was dark purple color which came from the batik dye, foamy, and smelly.

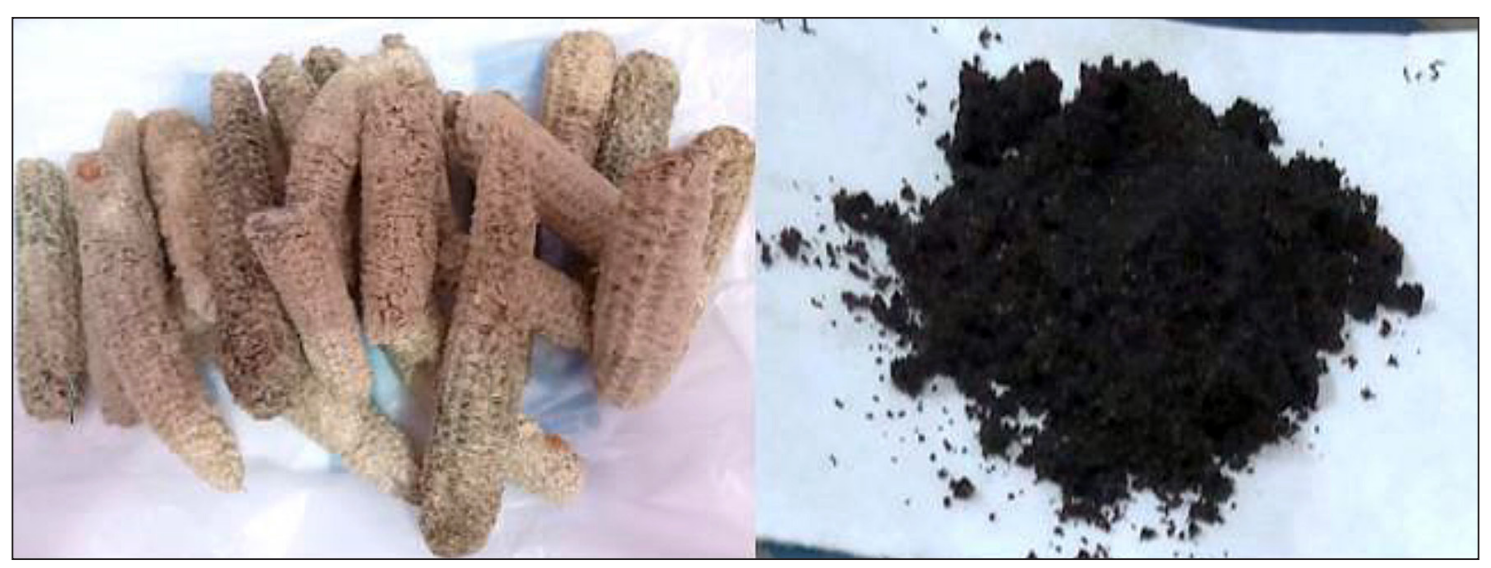

Figure 1. (a) Corn cobs. (b) Activated carbon from corn cobs (Research documentation, 2018)

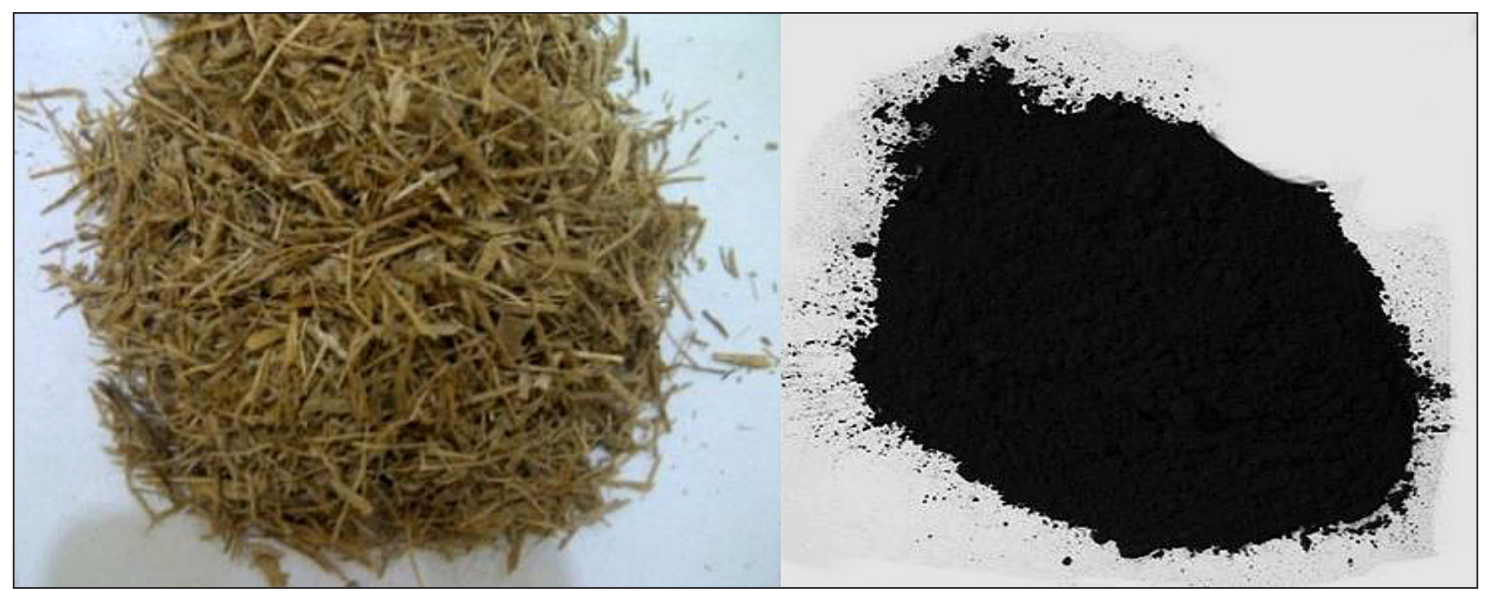

Figure 2. (a) Bagasse; (b) Activated carbon from bagasse (Research documentation, 2018) 


\section{Experimental design}

This study used a completely randomized factorial design (Figure 3). A completely randomized design in this study used a treatment factor, namely the difference in weight of activated carbon and the contact time of the batik waste with activated carbon. The activated carbons used were $0.5,1.5$, and $2.5 \mathrm{~g}$. Meanwhile, the contact times used were $30,60,90,120$, and 150 minutes. The dosage and contact time of the waste used in this study referred to the research by Alverina et.al (2014) and Nasir et al., (2015) with some modifications.

The 3-liter volume jars to be used were prepared and placed randomly. Then, $1000 \mathrm{ml}$ of batik waste was placed into the jar and activated carbon with doses of $0.5,1.5$, and $2.5 \mathrm{~g} \cdot \mathrm{L}^{-1}$. Then, the predetermined contact times of 30,60 , 90,120 , and 150 minutes were applied. After the specified contact time was complete, the temperature and $\mathrm{pH}$ measurements were taken.

Tthe adsorption capacity formula used is as follows:

$$
q=\frac{C_{o}-C_{1}}{m} V
$$

where: $q$ : Adsorption capacity $\left(\mathrm{mg} \cdot \mathrm{g}^{-1}\right)$

$C_{0}$ : Initial solution concentration $\left(\mathrm{mg} \cdot \mathrm{L}^{-1}\right)$

$C_{1}$ : Concentration of the solution after adsorption $\left(\mathrm{mg} \cdot \mathrm{L}^{-1}\right)$

$m:$ Adsorbent mass (g)

$V$ : Volume of solution (L)

\section{Measurement of physical and chemical parameters}

The measurement of the chromium $(\mathrm{Cr})$ levels used the AAS (Atomic Absorption Spectrometry) method (Nawrocka \& Szkoda, 2012), and water quality parameters namely temperature (thermometer) and $\mathrm{pH}$ (pH Hanna Instrusment HI 8424).

\section{Statistical analyses}

The statistical analyses in this study were a two-factor completely randomized factorial design (ANOVA test) and the least significant difference test. The analyses were performed using the SPSS 20.0 and MS Office Excel 2016 software.

\section{RESULTS AND DISCUSSION}

\section{The characteristics of batik waste after the treatment with activated carbon}

After given a contact treatment with activated carbon, there is no significant change; the only thing occurring is the batik waste which originally has smell turns to be odorless.

\section{Application of activated carbon with the batik waste}

The $\mathrm{Cr}$ content was measured after the batik waste was treated with activated carbon from corn cobs (Figure 4) at a dose of $0.5 \mathrm{~g} \cdot \mathrm{L}^{-1}$ and immersion time of 30 to 150 minutes is $0.11-0.03 \mathrm{mg} \cdot \mathrm{L}^{-1}$. In an experimental container given activated carbon at a dose of $1.5 \mathrm{~g} \cdot \mathrm{L}^{-1}$ and immersion time of 30 to 150 minutes, it ranges from 0.10 to $0.03 \mathrm{mg} \cdot \mathrm{L}^{-1}$. Meanwhile, for the batik waste which was given activated carbon at a dose of $2.5 \mathrm{~g} \cdot \mathrm{L}^{-1}$ and immersion time between $30-150$ minutes, it is $0.07 \mathrm{mg} \cdot \mathrm{L}^{-1}$ to $\leq 0.024 \mathrm{mg} \cdot \mathrm{L}^{-1}$ (not detected). It means that the value of the $\mathrm{Cr}$ content is below $0.024 \mathrm{mg}$. The value of $\mathrm{L}^{-1}$ cannot be ascertained because the limit of the AAS tool used for the analysis of the $\mathrm{Cr}$ content has a detection limit of only $0.024 \mathrm{mg} \cdot \mathrm{L}^{-1}$ so that for the purposes of statistical analyses, the lowest limit value that can be detected by the AAS tool was used.

\begin{tabular}{|l|l|l|l|l|l|}
\hline $\mathrm{Ab} 2$ & $\mathrm{Cc} 1$ & $\mathrm{Cd} 2$ & $\mathrm{Ba} 2$ & $\mathrm{Bd} 2$ & $\mathrm{Cc} 2$ \\
$\mathrm{Ba} 1$ & $\mathrm{Bb} 2$ & $\mathrm{Bc} 2$ & $\mathrm{Ab} 1$ & $\mathrm{Aa} 1$ & $\mathrm{Ca} 2$ \\
$\mathrm{C} 1$ & $\mathrm{Ae} 1$ & $\mathrm{Cb} 1$ & $\mathrm{Bd} 1$ & $\mathrm{Aa} 2$ & $\mathrm{Ac} 1$ \\
$\mathrm{Bc} 1$ & $\mathrm{Bb} 1$ & $\mathrm{Ce} 2$ & $\mathrm{Ad} 1$ & $\mathrm{Ae} 2$ & $\mathrm{Be} 1$ \\
$\mathrm{Be} 2$ & $\mathrm{Ad} 2$ & $\mathrm{Ac} 2$ & $\mathrm{Ce} 1$ & $\mathrm{Cd} 1$ & $\mathrm{Cb} 2$ \\
\hline
\end{tabular}

Figure 3. Research design:

A,B,C - Dosage of activated carbon (A: $0.5 \mathrm{~g} / \mathrm{L} ; \mathrm{B}: 1.5 \mathrm{~g} / \mathrm{L} ; \mathrm{C}: 2.5 \mathrm{~g} / \mathrm{L}$ )

a,b,c,d,e - Contact time (a: 30 minutes, b: 60 minutes, c: 90 minutes, d: 120 minutes, e: 150 minutes)

1,2 - Replication 


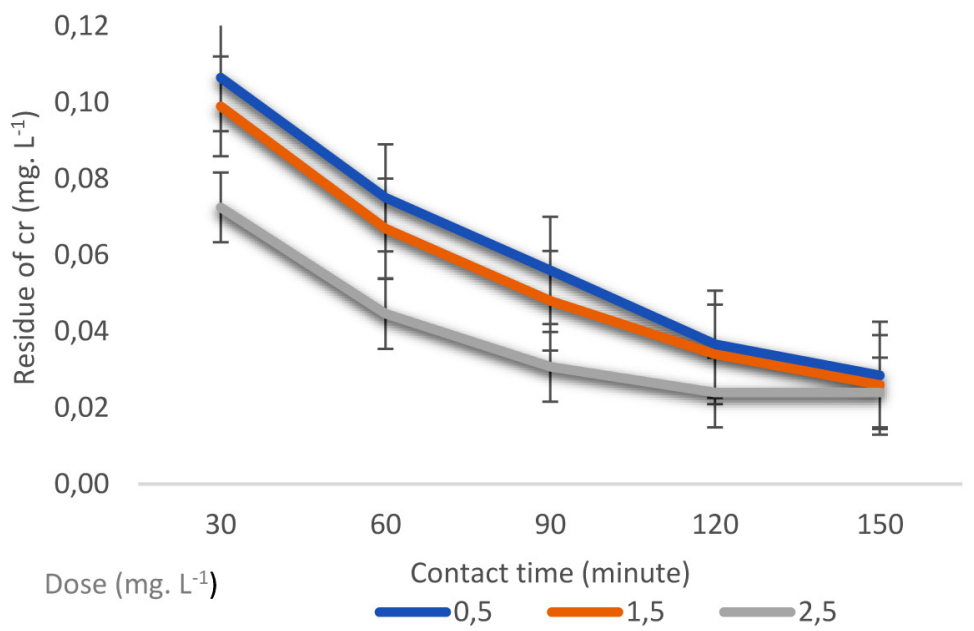

Figure 4. The graph of the chromium $(\mathrm{Cr})$ content decreases following corn cob activated carbon treatment

The result of the decrease of the chromium levels using bagasse activated carbon (Figure 5) shows that the chromium $(\mathrm{Cr})$ levels continue to decline from the initial concentration of $0.144 \mathrm{mg} \cdot \mathrm{L}^{-1}$. The batik wastewater given activated carbon at a dose of $0.5 \mathrm{~g} \cdot \mathrm{L}^{-1}$ and immersion time of 30 to 150 minutes has the chromium level ranging from 0.027 to $0.125 \mathrm{mg} \cdot \mathrm{L}^{-1}$. In an experimental container given activated carbon at a dose of $1.5 \mathrm{~g} \cdot \mathrm{L}^{-1}$ and immersion time of 30 to 150 minutes, it ranges from 0.024 to $0.114 \mathrm{mg} \cdot \mathrm{L}^{-1}$, and in an experimental container given activated carbon at a dose of $2.5 \mathrm{~g} \cdot \mathrm{L}^{-1}$ and immersion time of 30 to 150 minutes, it ranges from 0.024 to $0.112 \mathrm{mg} \cdot \mathrm{L}^{-1}$.

Figures 4 and 5 show that there is a decrease in the $\mathrm{Cr}$ content after given activated carbon with different doses and contact times until showing a value below the permissible limit of the chromium $(\mathrm{Cr})$ content in the waters of $0.05 \mathrm{mg} \cdot \mathrm{L}^{-1}$ (PP. No 28 of 2001). This decrease is due to the adsorption process by activated carbon. The content of cellulose, hemicellulose and lignin in corn cobs and bagasse makes charcoal a good ingredient for activated carbon. The content of cellulose $(45 \%)$, hemicellulose (35\%) and lignin (15\%) makes corn cobs one of the good activated carbon ingredients (Fitriani et al., 2013). Viewed from the pore structure at a certain carbonation temperature, cellulose is still stronger than lignin because at the temperature of around $500-800^{\circ} \mathrm{C}$ there is still an increase in the pore diameter of charcoal while for lignin at the temperature of $200^{\circ} \mathrm{C}$ there has been a damage in the pore walls, which shows

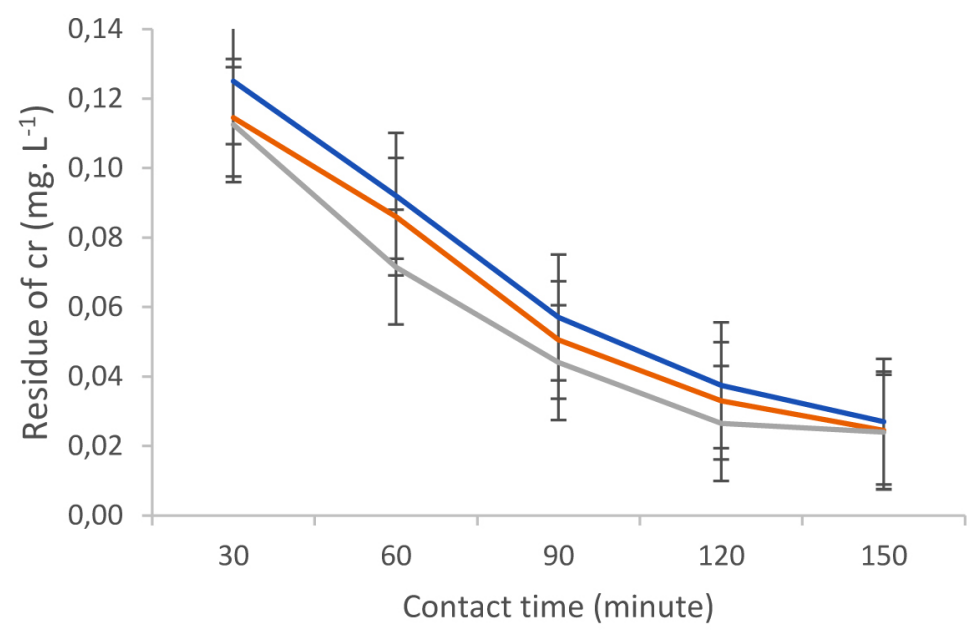

Dose (mg. $\left.\mathrm{L}^{-1}\right)$

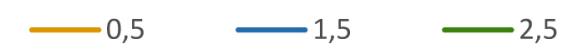

Figure 5. The graph of the chromium $(\mathrm{Cr})$ content decreases following bagasse activated carbon treatment 
the function of cellulose as a constituent of carbon framework in activated charcoal, resembling the structure of graphite (Pari, 2011).

The increase in adsorbent mass will also increase the percentage of the adsorbate absorption efficiency due to the increase in the metal binding groups (Barros et al., 2003). In addition, according to Nurdin (2006), the factor that affects adsorption is the amount of adsorbent density where the increase in the weight of the absorbent material also indicates an increase in the density of the absorbent material in the solution, so the highest absorption will be achieved at a certain density, which allows for an effective interaction between the metal ions and active adsorbent groups.

\section{Analysis results of a completely randomized factorial design}

The activated carbon from both corn cobs and bagasse was proven to be an adsorbent able to absorb the $\mathrm{Cr}$ content in the batik waste. This was proven by the results of statistical test analysis, while the differences in the dose of activated carbon used in this study were also proven to be able to reduce the $\mathrm{Cr}$ content in the batik waste. The result obtained for the dose treatment $(0.5$, 1.5, $\left.2.5 \mathrm{~g} \cdot \mathrm{L}^{-1}\right)$ of activated carbon from corn cobs is Fcount $>$ Ftable, which is $23.16>3.68$ (p $=0.05$ ), so it can be concluded that the decrease in the $\mathrm{Cr}$ content in the batik waste by treatment with different doses of activated carbon gives a very significant effect. Meanwhile, for the treatment time $(30,60,90,120,150$ minutes $)$ Fcount $>$ Ftable, which is $82.17>3.02(p=0.05)$, so the decrease in the $\mathrm{Cr}$ content in the batik waste with different contact times of activated carbon has a very significant effect. For the interaction of dose treatment and contact time of activated carbon, Fcount $<$ Ftable, which is 1.63 $<2.64(\mathrm{p}=0.05)$, so it can be concluded that the decrease in the $\mathrm{Cr}$ content in the batik waste with the interaction between the two treatments does not give a significant effect. Therefore, in general, it can be concluded that the treatment of activated carbon dose and contact time does not influence one another in the reduction of $\mathrm{Cr}$ in the batik waste using the activated carbon from corn cobs. If there is an insignificant change in combination treatments, then it is said to have an insignificant effect, which is assumed to happen due to the response change caused by error or residue due to the effect of random chance.
Therefore, the cooperation between the factors that are combined is said to be free from each other (Tenaya, 2015).

The statistical analyses for dosage treatment $\left(0.5,1.5,2.5 \mathrm{~g} \cdot \mathrm{L}^{-1}\right)$ of activated carbon from bagasse result in Fcount $>$ Ftable, which is $6.85>3.680(\mathrm{p}=0.05)$, so it can be concluded that the dose treatment in the decrease of the chromium content in the batik wastewater with different contact times gives a significant effect. The time treatments of $30,60,90,120$, and 150 minutes have the results of Fcount $>$ Ftable, which is $167.95>3.060(\mathrm{p}=0.05)$, so it can be concluded that the treatment of time to the decrease of chromium with different doses gives a significant effect. In turn, for the interaction of dose treatment and contact time of activated carbon, it was noted that Fcount $<$ Ftable, which is $0.49<2.64(\mathrm{p}=0.05)$, so it can be concluded that the decrease in the chromium level in the batik wastewater with the interaction between the two treatments does not give a significant effect. This shows that each factor has an effect on the decrease of the chromium levels, but if the two factors interact with each other, these factors do not have an effect on reducing the chromium levels in the batik wastewater.

On the basis of the results of the least significant difference test, it was found that the most effective reduction in the $\mathrm{Cr}$ content is using activated carbon from corn cobs and bagasse at a dose of $2.5 \mathrm{~g} \cdot \mathrm{L}^{-1}$ with a contact time of 120 minutes. This research show that the intensity of the reduction in the $\mathrm{Cr}$ content has reached the standard quality limit for liquid waste in the water on activated carbon as much as $2.5 \mathrm{~g} \cdot \mathrm{L}^{-1}$. After 120 minutes to 150 minutes, the decrease in $\mathrm{Cr}$ is not as much as at the initial treatment because the longer time it is used for soaking, the lesser the capability of the activated carbon to absorb heavy metal molecules is (Emelda et al., 2013). The molecular adsorption force of a solute will increase if the contact time with the activated carbon is longer. This long contact time allows the diffusion process and the attachment of the adsorbed solute molecules to occur better (Syauqiah et al., 2011). The atoms on the surface of the activated carbon substance have an unbalanced force compared to the arrangement of atoms in solid substances in general, so the foreign molecules will try to fulfill this imbalance, which makes these foreign molecules attracted to the carbon surface. 


\section{Water quality parameters}

Temperature and $\mathrm{pH}$ are the factors that influence the absorption of heavy metals by activated carbon. The data on the average temperature during this study can be seen in Table 1. In terms of physical factors, temperature and $\mathrm{pH}$ measured before and after treatment also change. After treatment, the temperature remains stable and the $\mathrm{pH}$ increases. The changes in physical factors of the batik wastewater can be caused by the absorption of organic and metal content in the batik wastewater by adsorbents so that the value changes after the treatment (Jamilatun and Setyawan, 2014).

Table 1 shows that the results of the temperature measurements in the experimental container given activated carbon tend to be stable during the experiment, amounting to $23-25{ }^{\circ} \mathrm{C}$. Adsorption at a quite high temperature increase (more than $30^{\circ} \mathrm{C}$ ) can cause damage to the functional groups present in the biomass after heating because it has exceeded the temperature tolerance (Rilyanti et al., 2007). The adsorption rate will increase along with the increasing temperature, and adsorption will also decrease with the decreasing temperature (Kasam et al., 2005). However, if the adsorption reactions that occur are exothermic, then the adsorption rate generally increases with the decreasing temperature. If the waters are polluted by heavy metals, then the toxicity characteristics of such heavy metals to the aquatic biota will increase along with the increasing temperature, while a good temperature range for aquatic organisms is between $18-30{ }^{\circ} \mathrm{C}$ (Shindu, 2005).

On the other hand, the $\mathrm{pH}$ content contained in the batik wastewater is quite high (alkaline) because during this research there were still remnants of wax, detergent and soap which could increase the $\mathrm{pH}$ content in it. This is in accordance with the argument of Laras et al. (2015) stating that the weight gain of activated carbon can affect the increase in $\mathrm{pH}$ due to the absorption of hydrogen ions $\left(\mathrm{H}^{+}\right)$by activated carbon so that the $\mathrm{pH}$ value will increase. At low $\mathrm{pH}(<2)$ the carbon surface is positively charged and results in an electrostatic repulsive interaction between the positively charged surface and the metal cations. When $\mathrm{pH}$ increases, there is an exchange of $\mathrm{H}^{+}$ from the carbon surface with the metal ions from the solution (Bansal, 2005). The effect of $\mathrm{pH}$ on the absorption of $\mathrm{Cr}$ metal is very significant, and with the increasing $\mathrm{pH}$ conditions from acidic to neutral $\mathrm{pH}$, the absorption capacity tends to decrease (Agustinus et al., 2013).

\section{CONCLUSION}

The activated carbon of corn cobs and bagasse has the potential to reduce the levels of chromium contained in the batik wastewater from an initial level of $0.144 \mathrm{mg} \cdot \mathrm{L}^{-1}$ to below $0.024 \mathrm{mg} \cdot \mathrm{L}^{-1}$. An effective dose of activated carbon which can reduce the chromium levels in the batik wastewater to below the quality standard is $2.5 \mathrm{~g} \cdot \mathrm{L}^{-1}$ with a contact time of 120 minutes

Table 1. Data on temperature and $\mathrm{pH}$ measurement during treatment

\begin{tabular}{|c|c|c|c|c|c|}
\hline \multirow{2}{*}{$\begin{array}{c}\text { Factor A (dosage) } \\
\left(\mathrm{g} \cdot \mathrm{L}^{-1}\right)\end{array}$} & $\begin{array}{c}\text { Factor B (contact } \\
\text { time) (Minute) }\end{array}$ & \multicolumn{2}{|c|}{ Activated carbon from corn cobs } & \multicolumn{2}{c|}{ Activated carbon from bagasse } \\
\cline { 2 - 5 } & 30 & Temperature & $\mathrm{pH}$ & Temperature & $\mathrm{pH}$ \\
\hline \multirow{4}{*}{0.5} & 60 & $24 \pm 0$ & $8.81 \pm 0.02$ & $25.0 \pm 1.41$ & $11.08 \pm 0.03$ \\
\cline { 2 - 5 } & 90 & $24.5 \pm 0.7$ & $8.80 \pm 0.04$ & $24.5 \pm 0.50$ & $11.09 \pm 0.01$ \\
\cline { 2 - 5 } & 120 & $24.5 \pm 0.7$ & $8.86 \pm 0.04$ & $24.5 \pm 0.70$ & $11.11 \pm 0.04$ \\
\cline { 2 - 5 } & 150 & $25 \pm 0$ & $8.83 \pm 0$ & $24.0 \pm 0.00$ & $11.07 \pm 0.01$ \\
\hline \multirow{4}{*}{1.5} & 30 & $24.5 \pm 0.7$ & $9.11 \pm 0.01$ & $25.0 \pm 0.00$ & $11.07 \pm 0.00$ \\
\cline { 2 - 5 } & 60 & $24.5 \pm 0.7$ & $9.12 \pm 0.04$ & $24.0 \pm 0.70$ & $11.02 \pm 0.00$ \\
\cline { 2 - 5 } & 90 & $24.5 \pm 0.7$ & $9.15 \pm 0$ & $23.5 \pm 0.70$ & $11.05 \pm 0.02$ \\
\cline { 2 - 5 } & 120 & $24.5 \pm 0.7$ & $9.15 \pm 0.02$ & $24.5 \pm 0.70$ & $11.04 \pm 0.00$ \\
\cline { 2 - 5 } & 150 & $25 \pm 0$ & $9.19 \pm 0.12$ & $23.5 \pm 0.70$ & $11.06 \pm 0.02$ \\
\hline \multirow{5}{*}{2.5} & 30 & $24.5 \pm 0.7$ & $9.24 \pm 0$ & $24.5 \pm 0.70$ & $11.06 \pm 0.02$ \\
\cline { 2 - 5 } & 60 & $24 \pm 1.4$ & $9.25 \pm 0.02$ & $23.5 \pm 0.70$ & $11.03 \pm 0.01$ \\
\cline { 2 - 5 } & 90 & $25 \pm 0$ & $9.25 \pm 0.06$ & $23.5 \pm 0.00$ & $11.07 \pm 0.01$ \\
\cline { 2 - 5 } & 120 & $24 \pm 1.4$ & $9.25 \pm 0$ & $24.0 \pm 0.70$ & $11.03 \pm 0.02$ \\
\cline { 2 - 5 } & 150 & $25 \pm 0$ & $9.25 \pm 0$ & $24.5 \pm 0.70$ & $11.08 \pm 0.01$ \\
\hline
\end{tabular}




\section{REFERENCES}

1. Agustinus, E.T.S., A.T. Musrsito dan H. Sembiring. 2013. Peningkatan daya serap karbon aktif terhadap ion logam hexavalent chromium (Cr VI) melalui modifikasi dengan cationic surfactant (earthlylinediamine). Jurnal Riset Geologi dan Pertambangan, 23(1), 13-24.

2. Alfiany, H., S. Bahri dan Nuakhriwati. 2013. Kajian penggunaan arang aktif tongkol jagung sebagai adsorben logam $\mathrm{pb}$ dengan beberapa akrivator asam. Jurnal Natural Science, 2(3), 75-86.

3. Alverina, N., U.P. Juswono dan L. Nuriyah. 2014. Efektivitas penyerapan logam berat $\mathrm{Cu}$ dan $\mathrm{Cr}$ oleh karbon aktif bonggol jagung dan karbon aktif sekam padi pada air lindi TPA (tempat pembuangan akhir) sampah. Universitas Brawijaya, Malang.

4. Amin, A., S. Sitorus dan B. Yusuf. 2016. Pemanfaatan limbah tongkol jagung (Zea mays L.) sebagai arang aktif dalam menurunkan kadar amonia,nitrit, dan nitrat pada limbah cair industri tahu menggunakan teknik celup. Jurnal Kimia Mulawarman, 13(2), 78-84.

5. Apriadi, D. 2005. Kandungan logam berat Hg, PB, dan Cr pada air, sedimen dan kerang hijau (Perna viridis L.) di Perairan Kamal Muara, Teluk Jakarta. Skripsi, IPB, Bogor.

6. Asbahani. 2013. Pemanfaatan Limbah Ampas Tebu Sebagai Karbon Aktif Untuk Menurunkan Kadar Besi Pada Air Sumur. Jurnal Teknik Sipil, 13(1), $105-114$

7. Bansal, R.C. and M. Goyal. 2005. Carbon Adsorption. CRC Press: New York.

8. Barros J.L.M., G.R. Maedo, M.M.L. Duarte, E.P. Silva, dan Lobato, 2003. Biosorption Cadmium Using The Fungus Aspergillus niger. J. Chem, 20, $1-17$.

9. Chand. Bansal. Roop. Meenakshi Goyal. 2005. Activated Carbon Adsorpsion. United States of America (USA), Lewis Publisher.

10. Diantariani, N.P. 2010. Peningkatan Potensi Batu Padas Ladgestone sebagai Adsprben Ion Logam Berat Cr (III) Dalam Air Melalui Aktivasi Asam dan Basa. Tugas Akhir. Jurusan Kimia FMIPA Universitas Udayana: Bukit Jimbaran.

11. Effendi, H. 2003. Telaah Kualitas Air : Bagi Pengelolaan Sumber Daya dan Lingkungan Perairan IPB. Bogor: Kanisius.

12. Emelda, L., Putri, S.M., \& Ginting, S.B. 2013. Pemanfaatan Zeolit Alam Teraktivasi Untuk Adsorpsi Logam $\mathrm{Cr} 3+$. Jurnal Rekayasa Kimia dan Lingkungan, 2(4), 166-172.

13. Fitriani, S. Bahri dan Nurhaeni. 2013. Produksi bioetanol jagung (Zea mays) dari hasil proses delignifikasi. Online Jurnal of Natural Science. 2(3),
66-74.

14. Idrus, R., B.P. Lapanporo dan Y.S. Putra. 2013. Pengaruh suhu aktivasi terhadap kualitas karbon aktif berbahan dasar temputung kelapa. Prisma Fisika. $1(1), 50-55$.

15. 1Iskandar dan Kustiyah, E. 2017. Batik sebagai identitas kulturan bangsa Indonesia di era globalisasi. Gema, 52, 2456-2472

16. Jamilatun, S dan M. Setyawan. 2014. Pembuatan Arang Aktif Dari Tempurung Kelapa Dan Aplikasinya Untuk Penjernihan Asap Cair. Spektrum Industri, 12(1), 1-112.

17. Kasam., A. Yulianto dan T. Sukma. 2005. Penurunan COD (chemical oxygen demand) dalam limbah cair laboratorium menggunakan filter karbon aktif arang tempurung kelapa. Logika. 2(2). 1-15.

18. Kristianto, S., S. Wilujeng dan D. Wahyudiarto. 2017. Analisis Logam Berat Kromium (Cr) Pada Kali Pelayaran Sebagai Bentuk Upaya Penanggulangan Pencemaran Lingkungan Di Wilayah Sidoarjo. Jurnal Biota. 3(2), 66-70.

19. Kurniawan. MW.. Purwanto. P.. Sudarno. S. 2014. Strategi Pengelolaan Air Limbah Sentra Umkm Batik Yang Berkelanjutan Di Kabupaten Sukoharjo. Jurnal Ilmu Lingkungan, 11(2), 62-72.

20. Kusumadewi, M.R., Suyasa, I.W.B., Berata I.K. 2015. Tingkat biokonsentrasi logam berat dan gambaran histopatologi ikan mujair (Oreachromus mossambicus) yang hidup di perairan tukad badung kota Denpasar. Ecotrophic, 9(1), 25-34.

21. Laras, N.S., Yuliani dan H. Fitrihidajati. 2015. Pemanfaatan Arang Aktif Limbah Kulit Kacang Kedelai (Glycine max) dalam Meningkatkan Kualitas Limbah Cair Tahu. LenteraBio, 4(1), 72-76.

22. Marsh, H., dan R.R. Fransisco. 2006. Activated Carbon. Netherlands Elsevier Science \& Technology Books, Ukraina.

23. Mason, C. 2002. Biology of Freshwater Pollution. Fourth Edition. Prentice Hall, England.

24. Nasir, L.H., M. Zakir dan P. Budi. 2015. Desilikasi Karbon Aktif Sekam Padi Sebagai Adsorben Hg Pada Limbah Pengolahan Emas Di Kabupaten Buru Propinsi Maluku. Indonesia Chimica Acta, 7(2), 1-11.

25. Nawrocka, A. and Szkoda, J. 2012. Determination of Chromium in biological material by electrothermal atomic absorption spectrometry method. Bull vet inst pulawy, 56, 585-589.

26. Nurdin, 2006. Pengaruh Massa Serbuk Biji Moringa oleifera Terhadap Adsorpsi Timbal (II). Media Eksakta, 2(2), 077-080.

27. Pari, G. 2011. Pengaruh selulosa terhadap struktur karbon arang bagian 1: pengaruh suhu karbonisasi. Jurnal Penelitian Hasil Hutan, 29(1), 33-45. 
28. Puspasari, R. 2006. Logam dalam ekosistem perairan. Bawal, 1(2), 43-47.

29. Puspita, U.R., A. . Siregar dan N.V. Hidayati. 2011. Kemampuan Tumbuhan Air Sebagai Agen Fitoremediator Logam Berat Kromium (Cr) Yang Terdapat Pada Limbah Cair Industri Batik. Terubuk, 39(1), 58-64.

30. Rilyanti, M., Buhani dan Fitriyah. 2007. Pengaruh Temperatur Pada Laju Adsorpsi Biomassa Sargassum duplicatum yang Diimobilisasi Dengan Polietilmina Glutaraldehida Terhadap Ion Logam Pb(II), Cu(II) dan Cd(II). J. Sains Mipa, 13(2), 139-142.

31. Sasongko, D.P. 2010. Identifikasi unsur dan kadar logam berat pada limbah pewarna batik dengan metode analisis pengaktifan neutron. Jurnal Ilmu Pengetahuan dan Tekonologi Telaah, 27, 22-27.

32. Setiyono, I. and Gustama, R.A. 2017. Pengendalian kromium (Cr) yang terdapat di limbah batik dengan metode fitoremediasi. Unnes Journal of Public Health, 6(3), 155-160.

33. Shindu, S.F. 2005. Kandungan Logam Berat $\mathrm{Cu}$, $\mathrm{Zn}$, dan Pb Dalam Air, Ikan Nila (Oreochromis niloticus) dan Ikan Mas (Cyprinus carpio) Dalam Keramba Jaring Apung, Waduk Saguling. Fakultas Perikanan Dan Kelautan Institut Pertanian Bogor, Bogor.

34. Shofa. 2012. Pembuatan Karbon Aktif Berbahan
Baku Ampas Tebu dengan Aktivasi Kalium Hidroksida. Skripsi, Fakultas Teknik UI, Depok.

35. Siregar, Y.D.I., Heryanto, R., Riyadhi, A., Lestari, T.H., Nurlela. 2015. Karakterisasi karbon aktif asal tumbuhan dan tulang hewan menggunakan FTIR dan Analisa Kemometrila. Jurnal Kimia Valensi : Jurnal Penelitian Dan Pengembangan Ilmu Kimia, 1(2), 103-116.

36. Steelyana, E. 2012. Batik, a beautiful cultural heritage that preserve culture and support economic development in Indonesia. Binus Bussines Review, $1-15$.

37. Syauqiah, I., Amalia, M., Kartini, H.A. 2011. Analisis variasi waktu dan kecepatan pengaduk pada proses adsorpsi limbah logam berat dengan arang aktif. Info Teknik, 12(1), 11-20.

38. Tenaya, I.M.N. 2015. Penagruh Interaksi dan Nilai Interaksi pada Percobaan Faktorial (Review). Agrotrop, 5(1), 9-20.

39. Udyani, K. 2013. Adsorbsi Deterjen Dalam Air Menggunaan Adsorben Karbon Aktif Pada Kolom Fluidasi. Jurusan Teknik Kimia, ITATS Surabaya.

40. Wirosoedarmo, R., Anugroho, F., Mustaqiman, A.N., Amanah, R., Gustinasari, K. 2020. Phytoremediation of chrome in batik industry wastewater using Cyperus haspan. Nanothechnology for Environmental Engineering, 5(2), 1-7. 